Anastasia V.Lyakhovich

\title{
EXPERIMENTS IN HAUSA LITERATURE: AN EXAMPLE OF DAN FULANI'S FICTION
}

Saint Petersburg State University, 7-9, Universitetskaya nab., St. Petersburg, 199034, Russian Federation

The article analyzes the main features of four works of Dan Fulani published in Hausa in the 1980s. The works under discussion may be considered to be a part of so-called "children's literature" or adventure literature, aimed both at children and young adults. Experimental both in their form and content Dan Fulani's novels express new literary tendencies. The analysis of fiction by Dan Fulani allows us to examine and to reveal the main tendencies that Hausa language and literature of early to mid 1980s exhibit. The article focuses on specific features of the detective novels under consideration: given description and comparison of main characters, the plot, main themes of the four works, and outlines the substance of experimental approaches by Dan Fulani. Refs 10.

Keywords: experimental writing, Hausa literature, Hausa fiction, detective, Dan Fulani.

\section{ЭКСПЕРИМЕНТАЛЬНОЕ ТВОРЧЕСТВО ДАН ФУЛАНИ В ЛИТЕРАТУРЕ НА ЯЗЫКЕ ХАУСА}

\section{А. В. Ляхович}

Санкт-Петербургский государственный университет, Российская Федерация, 199034,

Санкт-Петербург, Университетская наб., 7-9

Статья посвящена четырем произведениям Дан Фулани, опубликованным на языке хауса в Нигерии в начале - середине 80-х годов. Выбранные для исследования книги заслуживают внимания, поскольку являются первыми образцами детской детективной беллетристики в хаусаязычной литературе. В статье приводится анализ особенностей сюжетов книг, образов персонажей, указаны важнейшие темы, к которым обращается Дан Фулани. Кроме того, затронут вопрос авторства детективов. Высказывается предположение о том, что творчество Дан Фулани является одним из примеров совместной писательской деятельности британца Джона Хэра и автора нигерийского происхождения. История становления и развития художественной литературы на языке хауса обнаруживает и другие примеры сотрудничества подобного рода, в особенности на начальных этапах. Книги Дан Фулани отличаются экспериментальным характером как по форме, так и по содержанию; они свидетельствуют о появлении новых литературных форм и попытках их внедрения в уже существующую литературную традицию. В ходе рассмотрения материала мы приходим к выводу, что в книгах Дан Фулани присутствуют черты, в целом характеризующие процесс адаптации жанра детектива в африканских литературах. Жанр детектива до сих пор является сравнительно слаборазвитым в хаусаязычной литературе Нигерии, что, по-видимому, можно объяснить отсутствием подходящей читательской аудитории. Библиогр. 10 назв.

Ключевые слова: экспериментальная литература, литература хауса, детектив, Дан Фулани.

\section{Background}

Detective stories though originating from European literature are nowadays widely known throughout the African continent. Hausa literature of Northern Nigeria goes its own way with the development of this genre. The purpose of this study is to discuss detective stories of Dan Fulani published in Hausa, as these works may be considered to be ones of the first detectives in Hausa fiction.

(c) Санкт-Петербургский государственный университет, 2016 
The identity of the writer is quite ambiguous. Some sources suggest [1] that Dan Fulani was a Nigerian writer brought up in Northern Nigeria and educated at Ahmadu Bello University. The other sources say that it was none other than British explorer and author that published a number of books in Hausa under the pseudonym Dan Fulani $[2,3]$. We assume that the works of Dan Fulani could also appear as a product of a joint authorship between the two writers, Nigerian and British one.

Dan Fulani is one of the first writers to start the experimental writing of detective fiction in the Hausa language. Today, he has published more than twenty books, and only four of them are in Hausa.

The overwhelming majority of his works are written in English. That is why Dan Fulani can be regarded more as an English language writer. Nevertheless, he started his career writing his novels both in Hausa and English. His first books appeared in 1981. It was the most productive year for Dan Fulani, as he was in the mainstream of a rising literary movement ${ }^{1}$. That year, seven books of his were published. The Hausa language novels were only two: "Sauna da barayin banki" [5] and "Sauna, dan sandan ciki" [6]. They were published along with their English language analogues, "Sauna and the bank robbers" and "Sauna, the secret agent".

The next year, 1982, was marked by the emergence of four of Fulani's works, including one in the Hausa language, "Duniya budurwar wawa" [7].

Only 1986 saw the next crop of his novels. Two of them were reprintings, while the other two were issued for the first time. These were the Hausa language "Kowa ya kwana lafiya shi ya so" and its English language analogue "Sauna and the drug peddlers" [8].

In the next few years, some other works were written, but only in English. One of them was even translated into Swahili.

The creative writing of Dan Fulani can be traced mainly to a particular phenomenon in Nigerian literature - the so-called "children's literature"2.

The rapid emergence of literature for young people in Nigeria was originally connected with the educational policy of the British administration. In particular, it also contributed to the development of literature in the indigenous languages. As G. Furniss indicates, even the act of imaginative prose writing in Hausa "itself was the product of an aspect of colonial educational logic", and the first writers "were deeply involved with the colonial education system" [10].

The 1960s saw new growth in publishing children's literature, which was also "stimulated by the rapid expansion of education and the resulting need and market for supplementary reading materials" [9].

Characterizing Nigerian modern literature for young people, Virginia Dike divides these books into different groups: stories of everyday life relating to growing up and family life, educational stories (warning about drugs or HIV/AIDS), and stories about love, sex, and marriage. Within children's literature, "adventure remains a very popular category, with boy detectives taking on bank robbers, drug peddlers, smugglers, kidnappers, foreign looters, and other criminals" [9].

The fiction of Dan Fulani can be defined as adventure literature, aimed both at children and teenagers. As to teenagers' literature, Virginia Dike defines it in the following way: such books "also include action and adventure, but in an adult world. Many of them

\footnotetext{
${ }^{1}$ A detailed examination of this process is provided by [4].

2 See, for example, [9] on the "children's literature" in Nigeria.
} 
are stories of crime and detection, in which the hero, often aided by a beautiful female assistant, brings down robber kingpins, rapists, murderers, extortionists, scam artists, unscrupulous officials, and international criminals. In some cases the victims of crimes or their relations exact a terrible revenge. Others concern political intrigue or secret cults in the universities" [9].

\section{Experiment and tradition}

The books of Dan Fulani are an example of literature aimed at little children and teenagers.

His two first novels are connected to each other.

"Sauna da barayin banki" ("Sauna and the bank robbers") tells a story of a boy who lives in the village of Delengi in the family of his uncle. From the beginning, the author emphasizes the fact that his hero is very special. The twelve-year-old boy usually gives his relatives many troubles. Strange, unusual things constantly happen to him. Being young, he has experienced many wonders, and he himself is very different from other people. For this reason, he is considered to be an fool, or a simpleton. His name "Sauna" expresses the same meaning: "a wastrel", "a simpleton".

Having a very inquiring mind, Sauna one day gets involved in the plans of some robbers. He is kidnapped by them. Following their orders under compulsion, he is arrested on the charge of attempting to rob a bank. While in prison, Sauna finds new friends, and then goes through many hardships trying to find the criminals, save his life, and clear his name.

"Sauna da barayin banki" combines features of two genres - detective and adventure. This duality is expressed mainly through the images of two characters - Sauna and his friend Bello. Sauna represents the adventure element of the narrative. He is not smart, and doesn't investigate any crime. In reality, he is no more than a victim trying to escape death and come home safe. Not casually at the end it is stated: "You are very lucky, Sauna. So many times you were in danger and managed to come through everything safe and sound..." [5, p. 105]

On the contrary, Bello is used by the author to strengthen the detective line of the work. Bello tries to help Sauna. He becomes a key figure in the investigation. He is really smart, and this fact is often underlined by means of comparison with incompetent policemen.

These two heroes being created for a new literary genre seems to be very typical for Hausa culture, and can be traced to particular Hausa stereotypes.

Sauna represents a kind of trickster, who seems to be weak and not dangerous, but in the end always defeats (overcomes) people who desire to harm him. As for Bello, he is not a trickster, but a wise man. This type of character is a rare hero in Hausa oral or written texts. His role consists of helping people and establishing justice. The concept of uncovering truth, centered in the character of Bello, is undoubtedly connected in Hausa tradition with an image of a wise man such as malam, or a jackal. They often help people in difficult situations that can be regarded as solving a riddle.

Both types of characters - trickster and the man of wisdom - have much in common. They share in the genre of the intellectual game in Hausa culture. In Bello, we see a transformation of the traditional image of a wise man. This character can be regarded also as a detective-intellectual borrowed from classic detective fiction. 
The entire work of Dan Fulani is based on traditional Hausa stereotypes. The crime is evil, and must be punished. People who commit the crime are necessarily unsocial. They lack any moral principles, and are capable of anything.

Dan Fulani doesn't have any interest in researching human nature or social disasters. That is why typical social categories and concepts, some of which were mentioned above, prevail over the individual, personal element in this work.

Touching upon the questions of morals, Dan Fulani inevitably uses the principles in harmony with Hausa traditional literature. For example, at the end of the story, the criminals were punished and the heroes got the reward, which is a typical feature of religious literature. Another curious detail is an emergence of pathos in the last sentence, which could be more suitable for an epic text or Hausa combat literature: "Sauna, Bello and Comfort became history as men of courage who helped the country" [5, p. 107].

The sequel to this book, "Sauna, the secret agent", though being published the same year, changed the concept of the first book.

First, the main character Sauna was left by the author as the only detective figure. There is no character like Bello, whose intellectual capabilities are not a substantial part of the story any more.

The author partially changes his main character, Sauna, into a detective-intellectual. Sauna is not defined as a fool any more. Answering the question about his name, Sauna points out that he can not explain the meaning, but everybody who knows him believes that the meaning is "a boy for whom getting into troubles has become a calling/ an occupation" [6, p. 79]. The same idea is expressed in the title of the book - "Sauna, dan sandan ciki" or "Sauna, the secret agent".

So, we see that during the course of the story the hero undergoes a change. Sauna meets an old policeman who teaches him the basics of detective work. For example, when they travel together, the policeman asks Sauna to be very attentive, and to memorize every little detail of their fellow-travelers' appearance. Sauna coped with his task perfectly, and it gave him some key clues in the future investigation. This episode also reveals increased skills of the author, having found a good technique to introduce the majority of the characters, and to describe them all in detail.

Though we do not find a pure example of a classic detective hero in this book, still the story can be defined as intellectual. The plot is structured in the form of a game with characters. The main principle of the book: There is nobody to trust, enemies hide under masks of friends, while enemies turn out to be friends.

The plot is based on unmasking a criminal who has harmed the business of an old friend of Sauna's uncle. The crime consists in a number of subversive actions, so revealing the saboteur becomes the purpose of Sauna. Unlike the first story where he got the role of hunted-after victim, in the sequel he appears as a secret agent working undercover. His first mask is of a stable worker, then he pretends to be a Fulani boy. Sauna is an observer collecting useful information. This feature of the work is not typical for Hausa written and oral literature.

Some other elements also show an obvious influence of foreign popular culture. For example, here we meet a very special kind of criminal. Unlike the first book, representing a type of evil human nature, in the second one it is a madman. 
- You must know he is out of his mind, he has gone mad.

- Madness? What do you mean saying that he is out of his mind, what does it mean he has gone mad?

- I mean by that he is one obsessed with the desire of power, obsessed with the desire of wealth, obsessed with the desire of murder if it can help him to achieve his aim. [6, p. 106]

Another outstanding feature of the novel is humor. Humor is an unusual element, being seldom used in Hausa literature. Of all works written by Dan Fulani in Hausa, "Sauna, dan sandan ciki", is the only one containing humorous episodes. As an example, the following episode can be set. At the end of the story, friends of Sauna decide to escort him home, to protect him from new adventures which he finds extremely often. On the way, they meet a person with a long finger nail. As people with the same type of nails had been recognized during the investigation as members of a certain organization, Sauna asks his friend to guess the kind of organization to which he belongs. "Maybe SOS," Sauna says. The girl asks: "What's the organization titled SOS?" "Save Our Sauna," he replies. [6]

The last two works of Dan Fulani contrast deeply. After two books about Sauna, Dan Fulani created a story of a boy as well. The hero, named Sabo, is very similar to Sauna. He lives in the same village, Delengi, both have no parents, and live in the family of their uncle. Sabo also inherits the main feature of Sauna's character of being a troublemaker. At first sight, this new work seems to be a sequel of the previous books about Sauna. Nevertheless, under detailed consideration, it appears to be very different.

In the book, "Kowa ya kwana lafiya shi ya so", Dan Fulani for the first time touches upon the questions of bringing up the young generation, and in particular the struggle against drug addiction.

Unlike the first two novels, here didactics determines the entire plot, while the element of entertainment is kept only as a background. It is emphasized in preface that in addition to an amusing plot, there are also important statements made, for instance the idea that the drug trade is evil and drug use leads to deplorable consequences. Thus, this work is aimed to serve as "a warning... against drug use and taking medicines without doctor's prescription" [7].

A substantial part of the text includes detailed descriptions which illustrate the process of the illegal drug trade and youth drug addiction. As an example, the following dialogic fragment can be set:

- Dauda, you must give me the drug.

- Must I?

- Yes, you must! I need it so much. Don't you know what can happen if you start using drugs? You are unable to give up.

- So what happens if you don't take the drug?

- The feeling is as if you go through hell. If I don't have my dose, I shake all over. The perspiration stands on my forehead. I feel that my stomach and my head are full of snakes. The eyes are burning in fever. Oh! You must give me the drug.

- Only if you pay fifty Naira, got it?

- Haliru threw out his cigarette... His eyes have inflamed and turned red.

- Give me the drug, if you don't I'll kill you. 
- Sabo watched Haliru throw up his arms and seize Dauda's throat, he started to smother Dauda.

- Give it! Give it to me now! [7, p.52]

The first chapter of the book can be defined as an introduction. It is an episode where the uncle of Sabo, named Alhaji Isa Delengi, and his friend are arguing about the modern generation, discussing its manners and morals. From different positions they touch upon a question of modern education.

In the subsequent part of the book, Dan Fulani develops the theme of upbringing. He states that the degradation of the youth is caused mainly by the fact that parents are unable to have control over teenagers. One day, Alhaji Isa Delengi was insulted by a boy, and decided to talk to this boy's father. Alhaji demands to punish the boy, but gets an unexpected confession. The boy's father says: "He is impossible to manage. He hasn't spent a night at home for three weeks. Now he is staying at the market place, or sometimes at his wicked friend's place. There is nothing I can do. There is nothing I can do but watch." $[7$, p. 8]

The crime represented in the story is drug-dealing. This social problem is examined as being a result of the destruction of patriarchal life, and new ideas emerging. Outlining the difference between the village and the city was typical for the previous books of Dan Fulani. In "Kowa ya kwana lafiya shi ya so", this difference is finally formed as an opposition. Unlike his first writings, the action is set in a village isolated from the other world. Alhaji Isa Delengi, himself, is a wonderful example of a traditional person: he can't stand television and modern schools.

Drugs are something unknown to village people. It's evil, an illness which penetrates into the most remote places of the country, and nobody can consider themselves safe. The person who brings drugs into Delengi, almost never appears in the text. A stranger with dreadful eyes is the only description of the criminal, but it is not a description of a person. It is rather a depersonalized image, an allegory of a drug addiction and drug-dealing.

Drugs are a vicious invention of modern society, where people are obsessed by a desire for benefit and enrichment. An important idea about the moral decay of youth is put by the author into the mouth of Alhaji Isa: "...the lack of respectfulness and obedience is the source of suffering for our country. Everyone believes that the best for them is to be let to do everything they consider as necessary, everyone wants only to get more and more money". [7, p. 1]

The fourth and the last work written by Dan Fulani in the Hausa language is entitled "Duniya budurwar wawa", or "The world is the fool's damsel". In comparison with previous books, this one appears to be deeply touched with the influence of foreign popular culture. The plot is constructed with different elements brought from Indian, American, and English films and literature. These are terrorists in opposition to the government of their native country, and planning to drop a bomb on the capital. We have the capture of a plane under the threat of a bomb blast; a mad scientist who created the bomb, and a mad leader of the terrorists obsessed with the desire for political power planning political intervention.

The main character is portrayed in a different way. It is a young man by the name of Isa. He spent some years in England working for the BBC. 
"Duniya budurwar wawa" can be defined as an adventure and detective story without any signs of didactics. Unlike the previous books dealing mostly with social problems, here political questions are brought into focus. The plot is based on committing political crime. The situation described by Dan Fulani is anonymous, but still very recognizable, being typical for some modern countries.

Though adventures are predominant in the text, still some ethical concepts are given. As I've mentioned above, the criminal of the story is a mad man. In one scene, it is shown how he tries to convince the hero that his cruel plans are the right way of doing justice upon the tyrannical government. Isa can not understand such a position. In his opinion, nothing can excuse killing thousands of people.

So as we can see, this book is not aimed at children. There are many scenes and descriptions of violence. For the first time, more than one person is killed, and even more significantly, for the first time the hero himself commits murder.

This new main character is often praised, for example by the culprits. They say that they hadn't expected from him such cunning, strength of mind, and especially, courage. It is shown in the scene mentioned above, when Isa openly argues with a mad criminal. At the end of the story, he is also told that he should be a secret agent. The reason is very typical for all books of Dan Fulani, and very uncommon and strange for the detective genre itself: "I think we must hire you as a secret agent because you are extraordinary lucky" [8, p.91]. Two characters of Dan Fulani's books became policemen (Sauna and Bello). Isa rejected to work as a secret agent. It is an interesting interpretation of the character in the detective genre.

\section{Conclusions}

Detective stories, as well as love stories, have become one of the most rapidly developing and beloved spheres of mass literature all around the African continent. African writers read both classical and hard boiled detective fiction. That is the reason why these kinds of detective fiction are mixed in their own books. Trying to adapt to a new genre, they transform it to the level of their understanding, or to the level of already existing literary tradition. First, African detectives are experimental ones. M. D. Gromov, describing Swahili detective fiction, defines some works as "an adventure tale". Traditional ethics have much influence on this genre. That is why the essential feature of classical detective fiction, that "good always defeats evil", becomes so attractive for the African writer, and popular with the African reader. [10]

As to hard boiled detective fiction, it also has a very special adaptation in African literature. As M.D.Gromov indicates, "the characters who represent an image of 'ideal' detective or secret agent or soldier... are usually considered to be a modernized epic hero who has changed their bows and arrows for automatic weapons" [10, p. 59].

All these features characterizing the process of adaptation of the detective genre in African literatures can be attributed to Dan Fulani's fiction as well.

The only thing is that Hausa detective fiction, especially children's detectives, takes up a very small place in modern Hausa literature. We assume that the main reason is a lack of reading audience. Y.M. Adamu writes: "At this moment, November 2002, the most popular and best selling new authors of the Hausa Literary Movement are mostly female... This does not however mean that they are the best or that they write better than other male 
and female authors, but they are very popular with readers. It has been observed that the readers - most of whom are women - seem to prefer reading women's writing... The thrillers and detective stories of recent Hausa literature have mostly been written by male authors and have little appeal to women" [4, pp. 204-205].

So, we can say that writing of detective fiction in Hausa was disappointing for Dan Fulani, because it has not got any audience response or financial success. However, this experimental creative writing can not be underestimated, being an outstanding phenomenon in Hausa language literature.

\section{References}

1. Dan Fulani. Available at: https://en.wikipedia.org/wiki/Dan_Fulani (accessed: 12.08.2016).

2. John Hare (conservationist). Available at: https://en.wikipedia.org/wiki/John_Hare_(conservationist) (accessed: 12.08.2016).

3. John Hare. Available at: https://de.wikipedia.org/wiki/John_Hare (accessed: 12.08.2016).

4. Adamu Yusuf M. Between the world and the screen: a historical perspective on the Hausa literary movement and the home video invasion. Journal of African Cultural Studies, 2002, vol. 15 (2), pp. 203-213.

5. Dan Fulani. Sauna da barayin banki. Zaria, Hudahuda, 1981. 107 p. (In Hausa)

6. Dan Fulani. Sauna, dan sandan ciki. Zaria, Hudahuda, 1981. 112 p. (In Hausa)

7. Dan Fulani. Duniya budurwar wawa. Zaria, Hudahuda, 1982. 92 p. (In Hausa)

8. Dan Fulani. Kowa ya kwana lafiya shi ya so. Zaria, Hudahuda, 1986. 93 p. (In Hausa)

9. Dike V.W. Developing fiction for today's Nigerian youth. A Journal of African Children's and Young Adult Literature, 2006, vol.4, pp.6-17. Available at: http://www.sacbf.org.za/2004\%20papers/Virginia\%20 Dike.rtf (accessed: 12.08.2016).

10. Gromov M.D. Sovremennaia literatura na iazyke suakhili [Contemporary Swahili literature]. Moscow, IMLI RAN Publ., 2004. 320 p. (In Russian)

For citation: Lyakhovich A.V. Experiments in Hausa Literature: an Example of Dan Fulani's Fiction. Vestnik of Saint Petersburg University. Series 13. Asian Studies. African Studies, 2016, issue 4, pp. 82-89. DOI: $10.21638 / 11701 /$ spbu13.2016.409.

Received: January 15, 2016 Accepted: September 8, 2016

Контактная информация

Анастасия Викторовна Ляхович - кандидат филологических наук; anastasia_07007@mail.ru Lyakhovich Anastasia V. — PhD; anastasia_07007@mail.ru 